\title{
Öndüç Hediye: Gaziantep’te Yataküstü Geleneği ve İşlevleri
}

\author{
Cevdet $\mathrm{AVCI}^{1}$ \\ Öz
}

Geleneksel bilgi aktarım süreçlerinde törenler, anlatılar ve mekânlar kuşaklar arasında toplumsal bellek taşıyıcısı işlevi görür. Hayatın geçiş dönemleri olan doğum, evlenme ve ölüm etrafındaki inanış ve uygulamalar, sözlü kültür geleneğinin korunduğu alanlar içerisindedir. Evlenme törenleri, sosyal dayanışma ve ekonomik paylaşım modellerini yoğun biçimde barındıran uygulamaları içerir. Makalenin konusunu Gaziantep evlenme törenleri içerisinde yer alan yataküstü geleneği ve işlevleri teşkil etmektedir. Makalede, yataküstü geleneğindeki hediyeleşme biçiminin incelenip bu hediyeleşme biçiminin sosyal dayanışma ve kültürel aktarım işlevlerinin değerlendirilmesi amaçlanmıştır. Bu kapsamda halk bilgisi derleme yöntemlerinden gözlem ve görüşme teknikleri kullanılmıs, ayrıca anket tekniğine uygun soru formu hazırlanıp Gaziantep kent merkezinde ikamet eden kaynak kişilerden bilgi alınmıştır. Yataküstü geleneği, çeyiz yeni çiftlerin oturacakları eve götürülmeden önceki hafta içerisinde belirlenen bir günde kız evinde kadınlar arasında yapılan bir uygulamadır. Burada hazırlanan çeyiz davet edilen misafirlere sergilenir. Yataküstüne gelen misafirler, çeyizi tamamlayacak ve destekleyecek hediye getirirler. Bu hediyenin mahiyeti geçmişten bugüne eşya, altın ve para şeklinde değişiklikler göstermektedir. Yörede geçiş dönemleri ve diğer sosyal hadisler etrafındaki hediyeleşmeler için öndüç kelime kullanılmaktadır. Getirilen hediyede karşılıklılık ilkesi esastır. Hediyenin karşıllı̆g getirilmediğinde, daha önce verilmiş olan hediyenin mahiyetine göre bir şekilde bedel istenir. Yataküstüne getirilen hediyenin değerini akrabalık derecesi ve mütekabiliyet belirler. Yakın akrabalar çeyizin eksiklerini tamamlamakla yükümlüdür. Yataküstü geleneği, hazırlanan çeyizdeki hüner ve el becerilerinin sergilenmesini, kadınlar arasında eğlence, müzik, sözlü kültür ve edebiyat ile yeme-içme etkinliğini içeren bir toplanmadır. Buna bağlı olarak makalede, Gaziantep evlenme törenleri içerisindeki yataküstü geleneğinin çok yönlü sosyoekonomik ve kültürel işlevleri olduğu sonucuna varılmıştır.

Anabtar Kelimeler: Gaziantep, Dügün, Çeyiz, Halk ekonomisi, Hediye

\section{Öndüç Gift: Yataküstü Tradition and Functions in Gaziantep}

\section{Abstract}

In traditional knowledge transfer processes, ceremonies, narratives and spaces serve as social memory carriers between generations. Beliefs and practices around birth, marriage and death, which are the transition periods of life, are among the areas where the oral culture tradition is preserved. Marriage ceremonies include practices that heavily include social solidarity and economic sharing models. The subject of the article is the yataküstü tradition and functions in Gaziantep marriage ceremonies. In the article, it is aimed to examine the gift giving form in the yataküstü tradition and evaluate the social solidarity and cultural transfer functions of this gift form. In this context, observation and interview techniques, which are among the methods of collecting folk information, were used, and a questionnaire was prepared in accordance with the questionnaire technique and information was obtained from the source people residing in Gaziantep city center. The yataküstü tradition is a practice among women in the girl's house on a specified day in the week before the dowry is taken to the new couples' home. The dowry prepared here is exhibited to the invited guests. Guests who come to yataküstü gifts to complete and support the dowry. The nature of this gift has changed from past to present in the form of goods, gold and money. For gifting around the transitional periods and other social hadiths in the region, the forefree words are used. The principle of reciprocity is essential in the gift. When the gift is not paid for, the price is requested in a way according to the nature of the gift given before. The degree of kinship and reciprocity determines the value of the gift brought to the yataküstü. Close relatives are obliged to complete the shortcomings of the dowry. The yataküstü tradition is a gathering that includes displaying the skills and handcrafts of the dowry, entertainment among women, music, oral culture and literature, and food and beverage activities. Accordingly, in the article, it was concluded that the yataküstü tradition in Gaziantep marriage ceremonies has multifaceted socio-economic and cultural functions.

Key Words: Gaziantep, Wedding, Dowry, Public economy, Gift

Atıf İçin / Please Cite As:

Avcı, C. (2021). Öndüç hediye: Gaziantep’te yataküstü geleneği ve işlevleri. Manas Sosyal Araştırmalar Dergisi, 10(3), 1491-1505.

Geliş Tarihi / Received Date: 17.12.2020

Kabul Tarihi / Accepted Date: 14.03.2021

\footnotetext{
${ }^{1}$ Dr. Öğr. Üyesi - Gaziantep Üniversitesi Fen Edebiyat Fakültesi, cavci@gantep.edu.tr 


\section{Giriş}

Halk biliminin çalışma alanları ile araştırma yöntem ve teknikleri 19. yüzyıldan bu yana güncellenerek gelmiştir. Müstakil bir bilim dalı olarak halk biliminin ortaya çıkışıla birlikte halk kavramı etrafında yapılan tartışmalar, halk bilgisinin üretim, aktarım, tüketim ve paylaşım biçimlerine bağlı olarak sürmüştür. Köy ve köy çevresinde yaşayan halk ve onun kültürel hayatını araştırı inceleyen anlayış; coğrafyaya bağımlı olmaksızın aralarında geleneğe dayalı ortak bir faktörü paylaşan insan grubunun halk olarak tarif edilmesine evrilmiştir. Buna bağlı olarak halk bilgisinin çerçevesi genişlemiş ve halk bilimi çalışmaları kent folklorundan tekno-kültür çalışmalarına kadar geniş bir yelpazede varlık göstermiştir (bkz. Dundes, 1998, s. 139-157; Ekici, 2000, s. 2-8; Ersoy, 2018, s. 129-136). Bu bağlamda Sedat Veyis Örnek, diğer sosyal bilim alanlarında da olduğu gibi halk biliminin konularının eksiksiz ve herkesin üzerinde anlaşabileceği bir çerçevesini çizmenin zor olduğunu belirtmiştir. Ona göre bu konulardan birisi de halk ekonomisidir (2000, s. 17).

Halk bilimi çalışmalarında bir değer mesele de geleneksel inceleme konularının 21. yüzyılda yeni yaklaşımlarla ele alınmaya başlamasıdır. Bu kapsamda makalede incelenen hayatın geçiş dönemleri içerisindeki evlenme törenlerinden olan yataküstü geleneği, bir hediyeleşme biçimi ve işlevleri bakımından ele alınmışır. Gelenekler, kolektif bilinç ve dayanışmayı güçlendirme işlevleriyle toplumsal hayata yön verir. Bugünün şartlarında gelenekler vasıtasıyla, "sekülerleşme, bireyselleşme ve modernizasyona direnerek bir arada var olma temel fikri” (Karaman, 2010, s. 234) yenilenerek varllğını korumaktadır. Gelenekler bir taraftan bireyin ve toplumun kültürel ihtiyaçlarını karşılarken bir taraftan da ekonomik boyutu da olan dayanışma modelleri ortaya koyar. Bu çerçevede "kültürün ekonomi alanında çeşitli üretim ve tüketim alışkanlıkları, araç ve gereçler, alışkanlıklar ve gelenekler teşekkül ve tekâmülü" (Özarslan, Karataş, 2016, s. 26) ortaya çıar. Bununla birlikte Paul Connerton'un (1999, s. 71) da ifadesiyle toplumsal belleğin bir hatırlama biçimi olarak törenler, bireyi bir değer ve tutum kümesinin içine çeker. Böylece kuşaklar arası geleneksel bilgi aktarım süreçleri işlemiş olur.

Makalenin konusunu Gaziantep evlenme törenleri içerisinde yer alan yataküstü (çeyizüstü) geleneği ve işlevleri teşkil etmektedir. Makalede yataküstü geleneği içerisindeki hediyeleşmenin geçmişten bugüne varlığını sürdüren bir paylaşım ve yardımlaşma modeli olması boyutu ele alınmıştır. Değişen sosyo-kültürel ve ekonomik şartlarla birlikte hayatın geçiş dönemleri etrafındaki uygulamaların içerikleri değişse de törensel boyutu ve işlevlerinin devam ettiğini ortaya koymak amaçlanmıştır. Makalede halk bilgisi derleme yöntemlerinden gözlem ve görüşme ile anket yöntemine uygun olarak hazırlanan soru formu kullanılarak Gaziantep kent merkezinde yaşayan kaynak kişilerden konuyla ilgili bilgi alınmıştır. Ayrıca literatür taraması yapılarak içerik analizi tekniğiyle toplanan veriler değerlendirilmiştir.

Gaziantep evlenme törenleri içerisinde bulunan yataküstü geleneği, yörede çeyizüstü olarak da bilinmektedir. Yataküstü, hazırlanan çeyizin gelin ve damadın yaşayacakları eve götürülmesinden önceki hafta içerisinde davet edilen misafirlere sergilenmesi törenidir. Bu tören kız evinde yapılan ve yalnızca kadınların katılabildiği bir ev içi eğlencesi şeklinde tezahür etmektedir. Törene davet edilen misafirler evlenecek olan kızın çeyizine çeşitli hediyeler getirmektedir. Bu hediyelerin mahiyeti geçmişten bugüne farklllık göstermektedir. Nebi Özdemir'e (2008, s. 468) göre “Türk toplumunda 'ihsan, lutuf, inayet, hibe, bahş, bağış, behiyye, yadigar, hörmet, bahşiş, eşantiyon, çorba parası, çay puli' ve benzeri sözcüklerle de ifade edilen armağan ya da hediye ve dolayısiyla hediyeleşme, kültürü oluşturan bir gelenek, sosyal yaşamı meydana getiren ve ayakta tutan karmaşık bir sistem olarak kabul edilmelidir." Bu çerçevede yataküstüne getirilen hediyeler bir ev eşyası olabildiği gibi para ve altın da olabilmektedir. Getirilen hediyelerin ekonomik değeri akrabalık derecesine göre değişmektedir; yakın akrabalar daha büyük hediyeler getirmektedir. Yataküstüne getirilen hediyeler karşl1ıklılık ilkesine tabidir. Hediyeler, kayıt altına alınmakta ve karşı tarafin geçiş dönemleri etrafindaki kutlama veya taziyesinde geri götürülmektedir. Yörede bu hediyeleşme biçimine "öndüç" denilmektedir. Kelime ödünç kelimesinin ses değişikliğine uğramış halidir. Öndüç geri götürülmediğinde toplum tarafindan ayıplanmakta ve hediyenin değerine göre geri istenebilmektedir. Türk Dil Kurumunun Derleme Sözlüğünde (1977) öndüç kelimesi yöreye göre "ödünç; başta yürüyen, haberci, muştucu” şeklinde açıklanmaktadır. Gaziantep’te öndüç kelimesi, ödünç anlamında olup getirilen hediye için "Şu kişinin bende öndücü var." ifadesi kullanılmaktadır. Buna göre yataküstü geleneği törensel bir tüketim, yardımlaşma ve dayanışma alanı olarak çok yönlü işlevlere sahiptir.

Makalede öncelikle Türk kültüründe evlenme geleneği etrafindaki uygulamalar hakkında bilgi verilerek, bu uygulamaların sosyo-ekonomik işlevleri üzerinde durulacaktır. Daha sonra Gaziantep halk kültüründe düğ̈un ve çeyiz geleneklerine değinilerek yataküstü geleneği incelenecektir. 


\section{Evlenme Gelenekleri ve Sosyo-Ekonomik İşlevleri}

Sosyal bilimlerin temel araştırma ve inceleme alanları içerisinde olan kültür, farklı yönleriyle ele alınmıştır. Buna bağlı olarak da kültürle ilgili farklı bilim alanları tarafından pek çok tanım ortaya konulmuştur. İnsanın sosyal ve fiziki çevresiyle kurduğu ilişkiler bütünü olan kültür, hayatın her alanıyla ilgili etkinlikleri içerir. Tarihsel süreçte "coğrafya, cemiyet ve insan unsurlarıyla" (Kafesoğlu, 1997, s. 27) şekillenen kültür ve medeniyet yapıları, Sanayi Devrimi'yle ortaya çıkan ekonomik üretim-tüketim tarzlarına dayalı olarak da şekillenmiştir. Bu minvalde kentleşme süreçleriyle birlikte sosyo-kültürel çevre değişmiştir. Bronislaw Malinowski'nin yapmış olduğu kapsamlı kültür tanımı insanı bütün olarak ele almaktadır. Ona göre: "Kültür aile, klan, yerel topluluk, kabile ve ekonomik işbirliği, siyaset, hukuk ve eğitimsel faaliyetlerle örgütlenen gruplar gibi, önemli ve yaşamsal görevlere bağlı kurumlar etrafinda örgütlenen nesne ve davranışları içerir." (2016a, s. 141).

19. yüzylldan bu yana sanayileşme, kentleşme ve teknolojiye bağlı olarak kesintisiz işleyen değişimdönüşüm süreçlerinin etkilediği geleneksel ve törensel alanlar, kültürel hayatın temellerini teşkil eder. Tarih öncesi dönemden bugüne insanın dünyaya gelme haberiyle işlemeye başlayan kültürel süreçler belirli gelenekler çevresinde açıklanır. Örnek, gelenek kavramını açıklarken "bir kuşaktan ötekine geçirilebilen bilgi, tasarım ve yaşantı biçimi” (2000, s. 126) tespitinde bulunur. Ona göre sözlü ve yazılı olarak iki gruba ayrilan gelenekler, toplumsal hayatın düzenlenmesinde ve denetlenmesinde önemli rol oynar. "Nitelikleri bakımından genellikle tutucu olan gelenekler aile, hukuk, din ve politika gibi toplumsal kurumlar üzerinde daha etkilidir. Gelenekler, genellikle yasalardan çok daha geniş bir alanı yönetirler.” (Örnek, 2000, s. 126). Dursun Yıldırım (1989: 6) ise gelenekler toplamının kültürü oluşturduğunu belirterek şu tanımlamayı yapar:

"Milletlerin hayatinda, tarih sabnesinde göründüklerinden bu yana, varlkelarm, bütünlüklerini ve farkhlhklarm koruyan, ibtiyaģlarm her anlam da karșılayan düzenler görülïr. Süreklilik vasfina sabip bu düzenlere biz gelenek adm veriyoruz. Bunlarn sayısı, fonksiyonlar ve yapu özellikleri, ait olduklar milletlerin gelisme durumlarna ve ibtiyaçlarna göre değissir. Saynlar, özellikleri, fonksiyonlar ne olursa olsun, bir milletin hayatinda yer alan geleneklerin tümü, o milletin kültü̈rünü meydana getirir.”

Gelenek çatısı altında şekillenen sosyal normların ise toplumun bir arada yaşamasını ve kuşaklar arası bilgi aktarımının gerçekleşmesini sağlar. Birey doğum öncesinden itibaren belirli bir gelenek örgüsüyle çevrelenir. Toplumun bir üyesi olmayla birlikte, bu gelenek dairesine girer ve sosyal normlara uyarak toplumsal meşruiyet kazanır. "Sosyal normların ortak ve belirgin özelliği yaptırımlardır. Yaptırımlar (müeyyideler), sosyal denetimi sağlamak ve sosyal normların etkinliğini ayakta tutabilmek için bireylerin, grupların ve topluluğun üzerinde zorlayıc1, kınayıcı ya da özendirici, ödüllendirici tepkilerin ve baskılarını işletirler. Böylece, toplumda var olması gereken genel bir uygunlaşımı düzenler ve korurlar.” (Örnek, 2000, s. 121).

Özellikle sanayi öncesi toplumlarda gelenek olgusunun işlevleri hayatın bütününü kapsar. Bu makalenin odak noktasını teşkil eden sosyo-ekonomik dayanışma, paylaşım ve kültürel aktarım meselesi, geleneğin önemli işlevleri arasındadır. Bu çerçevede makalede ele alınan Gaziantep’te evlenme gelenekleri içerisindeki uygulamalardan "yataküstü", kent hayatı içerisindeki dayanışma ve paylaşım modeli olarak hediyeleşme yoluyla halk ekonomisinde üretimi destekleyici bir örnek teşkil etmektedir. Bu durum geleneğin çok yönlü işlevleriyle ilgilidir. Gelenek daireleri toplumsal birlikteliğin korunmasını ve toplumun yeni üyelerinin bu birlikteliğin meşru fertleri olmasını sağlar. Buna bağlı olarak da geleneksel bir uygulamaya katılanlar her aşamada maddi ve manevi etkileşim içerisinde olur. Bu süreç bir anlamda toplumsal ve kültürel yapının her tekrarda yeniden inşası anlamına gelir. Katılımcılar da bu inşa sürecine karşılıklı destek olurlar. Diğer taraftan geleneksel uygulamanın etkileri uygulandığı zamanın dışında da sürer. Bu şekilde toplumsal devamlılık sağlanmış olur ve uygulamaya katılanların grup bilinci gelişerek toplumsal kimlik algisı oluşur. Geleneğin kökeninde de toplumsal statü ve rol belirleyici olma özelliği yatar. İnsan hayatının geçiş dönemleri olan doğum, evlenme ve ölüm etrafindaki inanış ve uygulamalar, bireyin toplumsal statü ve rollerini değiştirir. Buna bağlı olarak sosyal yapıda bir takım değissiklikler ortaya çıar. "Söz konusu sosyal yapıda meydana gelen değişikliklerin mevcut yapıyla çatışan durumlar oluşturmasının önüne ise törenler sayesinde geçilmektedir. Zira törenler sosyal yapıdaki bu tür dönüşümleri, çatışmaları engelleyerek ya da yaşanan dönüşümü meşrulaştırarak sağlar." (Karaman, 2010, s. 232, 235). Richard Sennett $(2012$, s. 110, 111) töreni, iletişim davranış1 olarak açıklar ve ona göre bir törenin kutsallığ1 gelenekten gelir ve "kökleri zamanın buğusuna" gömülür. 
Geleneksel yaşam biçiminde sosyal dayanışma, yardımlaşma ve paylaşım toplumun devamlılı̆ı̆ı sürdürmesi için temel oluşturur. Bu çerçevede sözlü anlaşma ve uygulamalar yoluyla bir arada yaşayan toplumda yardımlaşma ve paylaşım biçimleri ilkel toplumdan bugüne varllğını sürdürmüştür. Bu yardımlaşmanın üretime dayalı bir modeli olarak halk ekonomisi, birtakım gereksinimlerin para yerine çeşitli mübadele araçlarılyla karşılanma biçimi olarak görülür. Halk bilimi çerçevesinde halk ekonomisi, "halkın, geçim ihtiyaçlarını karşılamak amacıyla yaratıp geliştirdiği veya edindiği üretim ve tüketim biçimlerini, alışkanlıkları, davranışları ve bu süreçte kullandığı geleneksel yol, yöntem, araç ve gereçlerin tümüne karşllk gelmektedir." (Özarslan, Karataş, 2016, s. 19). Anadolu'nun çeşitli bölgelerinde halk ekonomisi örneği uygulamalarını bugün de görmek mümkündür. Örneğin, "hab" ve "değişik/deniş " geleneği bu uygulamalar içinde, bir halk ekonomisi faaliyetidir. Bu uygulamanın ekonomik olduğu kadar çeşitli kültürel ve ahlaki işlevleri de vardır. Karşllklı çıkarları gözetmek ve iştirak eden ailelerin yakınlaşması, hayatın diğer alanlarında da birlikteliği sağlar (Düzgün, 1991, s. 51; Özarslan, 2005, s. 58).

Halk hayatında ekonomik paylaşım ve yardımlaşma biçimlerinden birisi de hediyeleşmedir. Malinowski (2016b, s. 236) kültür tarihinde ekonomik ilişkilerde eşya ve iş mübadelesinin esas olduğunu belirtir. Bu sürecin işleyişinde mütekabiliyet esastır. İki tarafa da ekonomik fayda getiren hediye alışverişi de bu mütekabiliyet zincirinin bir parçasıdır. Bu bağlamda Türk halk kültürü içerisinde hediyeleşme vasıtasıyla ortaya çıkan yardımlaşma örneği olarak evlenme gelenekleri etrafında şekillenen çeşitli uygulamalar mevcuttur. Dügün öncesi, esnası ve sonrası uygulamalar bunlar içerisindedir. Geleneksel Türk kültüründe düğün bir bütün olarak sosyal yardımlaşma ve dayanışma alanıdır. Genel itibariyle düğün bir paylaşım modelidir. Ali Duymaz'ın (2005, s. 37-60) ifadesiyle "Türk kültür tarihinde destan metinlerinde görülen toyların her birisi bir paylaşım modelini teşkil eder. Evlilik etrafinda gelişen törenler ve evlilik toyları da bu paylaşım modellerinden birisidir."

İnsan hayatını her yanıyla etkileyen geçiş dönemi törenlerinden birisi dügündür. Evlilik hareketi içerisinde önemli bir dönüm noktası teşkil eden düğün, eski Türklerden bu yana Türk kültürünün önemli bir parçasıdır. Değişen sosyo-kültürel ve ekonomik şartlar, düğün geleneğinde birtakım değişimlere sebep olmuş; ancak geleneksel kültür unsurları muhafaza edilmiştir. Düğ̈̈n kelimesinin kökeniyle ilgili olarak Ali Yakıcı'nın (1991, s. 33) tespit ettiği iki temel yaklaşım vardır. Buna göre düğün, “toy günü” ya da "tü günü” kelimeleriyle ilişkilidir. İkinci görüşe göre ise düğün kelimesinin kökü "düğmek" bağlamak, düğümlemek demektir. Dolayısıyla düğün, iki tarafın birbirine söz vermesi ve bağlanması anlamında kullanılmaktadır. Dügünün eğlenceli, çalgıll, yemekli toplantılar için kullanımıysa sonradan gelişmiş ve "evlenme veya sünnet münasebetiyle yapılan ziyafetli ve eğlenceli şenlik ya da köy şenliğ̣i" (Tietze 2002, s. 669) anlamı gelişmiştir. Tuncer Gülensoy (2007, s. 311düğünün iki kişinin birbirine bağlanması olayı olduğunu söyler; ona göre kelimenin kökündeki "tüg” -bağlamak fiili bunun ispatıdır. Dolayısyla toyla ve eğlenceli toplantıyla ilişskilenmesi sadece bir boyutudur. Türklerde düğ̈n töreninin ortaya çıkışılla ilgili olarak Adem Öger'in (2008, s. 515) Alp Er Tonga ve onunla ilgili Uygurlar arasındaki sözlü anlatıları ele aldığ yazısında verilmektedir. Buna göre halkın sorunlarına çözüm bulan bir yönetici olarak tarif edilen Alp Er Tonga, kalabalık ve toplu yaşamın başlamasıyla birlikte ortaya çıkan toplumsal yapıda, karşı cinsle olan ilişkileri düzene sokmak ve karışıklıkları önlemek için çare düşünmüştür. Alp Er Tonga erkek ve kızın evliliğini dügün merasimi yaparak halka duyurma yoluyla barış ve düzeni sağlamıştır. Bu dönemden sonra dügün Türk kültürünün ayrilmaz bir parçası olmuştur.

Türk kültür tarihinde evlenme gelenekleriyle ilgili tartışlan konulardan birisi evliliğin ekonomik boyutudur. Bahaddin Ögel'in ele aldığı "kalın" adı altında kızın ailesine verilen maddi bedel de bu kapsamdadır. Bu gelenek bugün de varlığını kalın ve başlık adı altında sürdürmektedir. Popüler kültür içerisinde yapılan yüzeysel tartışmaların dışında kalın ya da başlık, tarihsel süreçte halk hukuku çerçevesinde ele alınması gereken bir konudur. Kadının bir iş gücü olarak görülmesi ve o iş gücünün güvence altına alınmasıyla ilgili bir durum olan kalın verme-alma geleneği, Ögel’e göre (Ögel 1982, s. 393), "ailenin kuruluş ve geleceğini düzenleyen bir depozit" işlevindedir. Ayrıca bu bedel kaybolmaz ve unutulamaz. Diğer taraftan evlenmeyle ilgili bir kültür kalıbı olarak başlık parası dünyanın pek çok ülkesinde görülebilmektedir. Mahmut Tezcan (1998, s. 1) bugün de devam eden bu geleneğin, belirli kültür bölgelerinde yaygın olmasına dikkat çeker. İslam toplumlarıyla Afrika, Çin, Endonezya, Melanezya, Burma gibi bölgeler bu duruma örnek teşkil etmektedir. Başılı parası kadının satılmasıyla değil; geleneksel kültür yapılarında birtakım hukuksal hakların aktarımıyla ilgili bir durumdur. Kalın ya da başlık uygulaması, maddi bedeli olan çeşitli eşyalar, hayvanlar, altın veya para olabilmektedir (bkz. Yüksekkaya, 2007, s. 396-406).

Sosyo-ekonomik işlevlerle birlikte hayatın geçiş dönemi törenleri etrafında şekillenen "düşünce, tasarım, tutum, davranış, işlem ve uygulamalar" bir toplumun kültür kodlarını ortaya koymada önemli veri 
alanlarıdır. Hayatın bu üç önemli aşamasının çevresinde birçok "inanç, adet, töre, tören, ayin, dinsel ve büyüsel özlü işlem kümelenerek söz konusu "geçiş"leri bağlı bulundukları kültürün beklentilerine ve kalıplarına uygun bir biçimde yönetmektedirler." (Örnek, 2000, s. 131)

Nedim Bakırc1 (2019, s. 132, 141) Dede Korkut Kitabında geçen toyları sıralarken bir geçiş dönemi töreni olarak düğün toylarını da ekler. Bu toyların işlevleri toplumda birlik ve beraberlik, dayanışma, paylaşma, sevinç ve üzüntülerin ortaklaşa yaşandığı törenler şeklinde gelişmiştir. İslâm dininin kabulüyle birlikte yerleşik hayata geçişin de etkisiyle ve Anadolu'daki Türkler arasında söz konusu şölenler farklılaşarak devam eder. Ancak özellikle düğün âdetleri içerisinde eski kültür izleri yaygın olarak görülür. Ögel (1998, s. 342) bu durumu exogamie evlilik biçimiyle örneklendirir. Dügün türkülerinde geçen "yad ellerden", "el oğlundan” gibi şikayetlerle örülü metinler bunun göstergeleridir. Ona göre: "Türk düğünü, aile müessesesi tekâmül vetiresinde muhtelif safhalar geçirdikten sonra, her safhada meydana gelen âdetleri içine alarak, muhtelif ve birbirine aykırı unsurlardan mürekkep bir merasim haline gelmiştir.” (Ögel, 1998, s. 349).

$\mathrm{Bu}$ katmanlı yapısıyla kompleks bir tören ağına dönüşen düğün geleneği içerisindeki kültürel unsurların çeşitli işlevleri vardır. İnsan, mekân ve tören arasındaki ilişkinin yoğun olarak yaşandığı düğün törenleri "birleştirici canlandırıc1, eğlendirici, mutluluk verici fonksiyonlar1 ile Türk kültürünün yap1 taşlarından biri olma vasfinı her zaman koruyacaktır." (Öğüt-Eker 1998: 5). Düğün yalnızca tarihî süreçte değil; değişen sosyo-kültürel şartlarla bugün de benzer işlevlerini sürdürmektedir. Umay Günay'ın (1991, s. 12) ifadesiyle, "Folklor hadiselerinin yeni hayat tarzımız içinde değişmeleri, bir ölçüde kaybolmaları, bu mahsullerin tabiatları gereğidir." Bu çerçevede düğün geleneği etrafindaki uygulamalar, kentleşme ve elektronik kültür gibi etkenlerden dolayı değişime uğramış olsa da genel yapısını muhafaza etmektedir. Düğün, geçmişten bugüne Türk kültüründe "bir eğlence ve birlik unsuru" (Berber, 2009, s. 1-11) olma niteliğini korumuştur.

Bu çalışmanın konusunu teşkil eden dügün öncesindeki çeyiz geleneği, mütekabiliyet esasına dayalı sosyal paylaşım ve dayanışma modeline örnek teşkil etmektedir. Çeyiz, hazırlanış ve etrafında gelişen törenlerle birlikte el sanatları, giyim-kuşam, yeme-içme, oyun-müzik, halk inanışı gibi pek çok halk kültürü unsurunu barındırır. Çeyizle ilgili önemli noktalardan birisi hediyeleşme unsurudur. Hediyeleşme, Türk evlilik gelenekleri içerisinde önemli bir yer işgal eder. Örnek (2000, s. 198) bu dururumu şu şekilde açıklar:

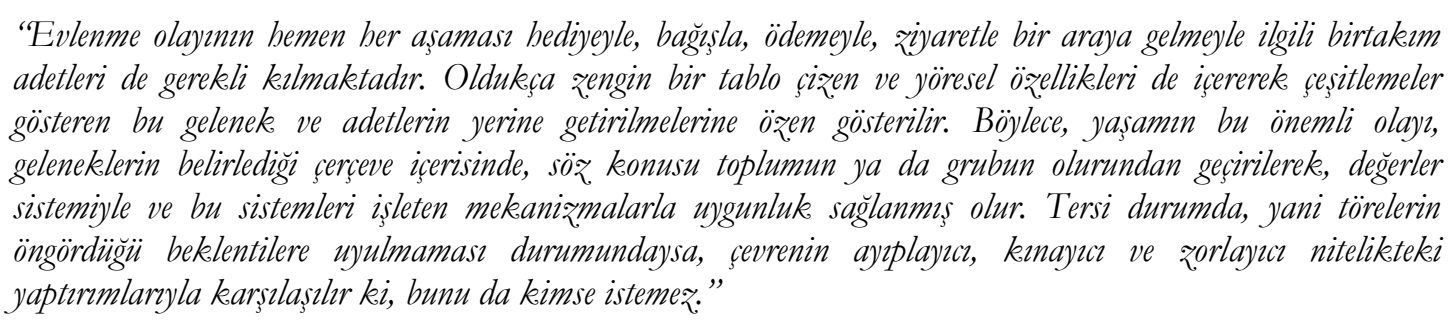

Türk kültüründe çeyiz henüz çocukluk döneminden itibaren hazırlanmaya başlanır. Boratav'ın (1994, s. 155) bu konuda ilk tırnakla ilgili aktardığı gelenek durumu örneklendirmektedir. Çocuğun ilk tırnağı kesildikten sonra eli altın paralar konulan bir torbaya sokturulur. Çocuğun oradan aldığı miktar, çocuk erkekse gelecekte kuracağı işe sermaye olarak; kız çocuklarda ise alınan miktar gelecekte çeyizi için kullanılacak ilk maya olarak saklanır. Çeyiz, gelin için hazırlanan, kız evinin yaptığı veya aldığı her türlü şahsi eşya ve ev eşyasını içerir (Öğüt-Eker, 1998, s. 145; Yeşil, 2014, s. 184). Çeyiz, sosyo-kültürel ve ekonomik açıdan bir gösterge olarak algılanır. Bu bağlamda "Çeyiz, kızın baba evinden erkek tarafina götürdüğü armağan niteliğinde ve daha çok ev eşyalarından oluşan şeylerdir. Birçok aile bu yüzden önemli miktarda borca girer. Çünkü alınan başlığın miktarından daha fazlası çeyiz olarak kıza verilir. Çeyiz miktarının çokluğu ailenin saygınlığını arttı1ır." (Tezcan, 1998, s. 2). Çeyizin bir sosyal dayanışma ve paylaşım biçimi olduğunu belirten Gülin Ögüt Eker (1998, s. 150), aileyle birlikte bütün akrabaların dâhil olduğu bir hazırlık sürecinden geçtiğini aktarır. Ayrıca, Türk çeyiz kültürünün muhtevası ve geri planıyla ilgili şu tespitleri yapar:

"Yallardan beri süregelen sözlü kültür geleneğimizin temsilcisi kabul edilen çeyiz, krz evinin sosyal statüsünü

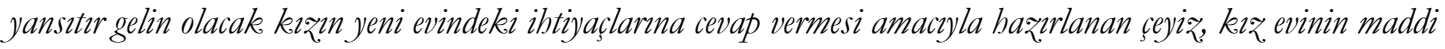
durumunun yaninda sosyal ve kültürel durumunun da bir göstergesidir. Ceyiz̨in vazgę̧ilmez, parçalar olan nakışlar, oyalar, danteller ve bu işlemelerde kullanulan motifler, onlar icra eden amatör sanatçlarn, dolayssylla 
o toplumun, yaşayışıı, coğrafi, ekonomik şartlarmı, sosyal hayatmı, değer yargzlarm ve tasarm gücünü ortaya koyan kriterlerdir." (Ögüt-Eker, 1998, s. 147-148).

Çeyizle ilgili Türkiye'de kullanılan terimleri “ağırlık götürme, atıntı atma, bedesten bozma, biçim bohça çıkarma, cehiz asma-çeyiz serme-çeyiz dizme, çehiz götürme, çehiz yazma, defter götürme, düzgüne gitmek, harç-görme, kalın götürme, keten kesme-urba görme, urba kesimi-yöngöş, pazarlık görme, pırt, urba görme, veç götürme, yatak biçme, yün götürme" şeklinde sıralayan Doğan Kaya (1996, s. 25), bunların dışında Anadolu'nun çeşitli yerlerin başka kullanımların da olabileceğini belirtir. Bu bağlamda Gaziantep’te kullanılan “yataküstü” veya "çeyizüstü” adlandırması da bu terimler arasında sayılabilir.

Çeyizin hazırlanış sürecinde yöreye göre farklılık gösteren eşyalar, el işleri, çeşitli nakışlar, kullanılan renk ve motifler aynı zamanda birer "sözsüz iletişim dili”" (Nas, 2018, s. 991-1005) özelliği taşır. Geleneksel kültür çevresi içerisinde kadının kendini estetik ve düşünsel olarak ifade araçlarından birisi olan çeyizdeki bu unsurlar birer sözsüz metindir. "Söz konusu anlatımlarda doğal, çevresel ve duygusal etmenler birer esin kaynağı olarak görsel nesnelere dönüşerek iletişim kurmanın en kısa ve en etkili yolu olmuştur." (Nas, 2018, s. 1002). Kızın kendisi ve ailesi tarafindan çeyizlik eşyaların yanı sıra, bu süreci ekonomik olarak da destekleyecek şekilde hediyeleşme geleneğinin de güçlü bir şekilde yaşadığı görülür. Bunlar çeşitli eşyalar olabildiği gibi ekonomik değeri olan ziynet eşyaları da olabilir. Genel olarak "takı" şeklinde adlandırılan bu eşyalar "altın, beşibiryerde, kremse, bilezik, yüzük, saat vb. hediyeler" olabilir (Örnek, 2000, s. 199). Bu hediyeleşme tarzının temelinde karşılıklılık ilkesi yatar. Tezcan'ın (2008, s. 56) da ifadesiyle çoğu toplumda görülen bu durum Türk kültüründe titizlikle işletilir. Çeyize gelen hediye kayıt altına alınır ve ona denk-eşit hediye götürülür. Getirilen hediyeler herkese açık bir şekilde sergilenir. Bu durum düğün töreni etrafindaki hediyeleşme geleneğinin dinsel, ahlaki ve ekonomik işlevselliğini gösterir. Tezcan, (2008: 59) hediyenin işlevlerini; dostluklar oluşturulup pekiştirme, yakınlık sağlama; dayanışmanın artırılması, yardımlaşmaya yol açma, destekleme; geleneklerin sürdürülmesi; konum belirleme, saygınlık kazanma; tüketime yol açma; kimliği ifade etme şeklinde sıralar. Emine Gürsoy Naskali (2007, s. 9) hediyeleşmenin şu yönlerine dikkat çeker:

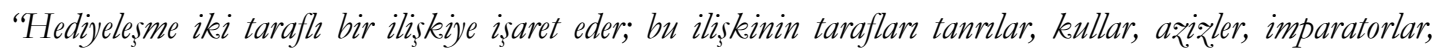

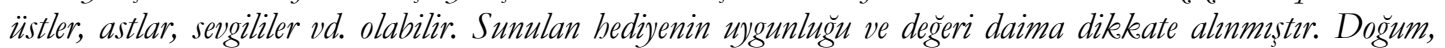
nişan, dï̈̆̈̈̈n, ölüm gibi toplum hayatında geçis dönemini belirleyen dönüm noktalarnnda nelerin verileceğgi

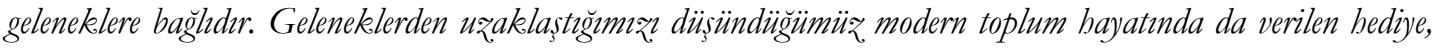
farkh kistaslarla da olsa, yine hassas bir segimdir."

Evlenme törenlerinin farklı kültürlerdeki dayanışma temelli işleyişi (Durkheim, 2006: 88), çeyiz çevresinde gelişen pratiklerde somutlaşır. Aileyle birlikte toplumun da evliliğin bütün süreçlerinde ekonomik olarak destek olduğu görülür. Böylece geleneksel tutuma dayalı bir dayanışma modeli kuşaklar arasında aktarılmış olur. Diğer taraftan çeyiz içerisindeki el sanatlarının da sürekli yeniden üretimi ve aktarımı sağlanır. Çeyiz etrafindaki âdet ve inanışlar "sosyo-kültürel" ve "ekonomik" (Karakelle, Özbağ1, 2019, s. 685) açıdan üzerinde durulması gereken konulardır. Bu süreç bir ailenin toplumsal statüsünü de içinde barındıran "törensel tüketim” (Durutürk, 2008, s. 41) örneğini teşkil eder. Türk kültüründe kolektif tüketime dayalı dayanışma ve yardımlaşma örneklerinden birisi çeyiz hazırlığı ve çeyiz törenidir. Zamanın şartlarını göre değişiklikler gösterse de çeyizin sosyal birleştirici özelliği bugün de devam etmektedir (ÖğütEker, 1998, s. 151; Mandaloğlu, s. 2012: 229).

\section{Bir Yardımlaşma Modeli Olarak Gaziantep'te Yataküstü (Çeyizüstü) Geleneği}

Gaziantep halk kültüründe evlenme gelenekleri zaman içerisinde değişiklik göstermekle birlikte bugün de zengin içeriğini muhafaza etmektedir. Çalışma kapsamında bu değişim sürecini tespit edebilmek adına Gaziantep Kültür ve Başpinar dergilerinde yapılan taramalarda 1950’lerden itibaren kent merkezli Gaziantep kültür hayatında hızlı bir değişimin yaşandığını gösteren halk kültürü yazıları derlenmiştir. Şakir Sabri Yener'e göre (1947b: 15) "Gaziantep evlenme âdetlerinin folklor bakımından pek çok teferruatı vardır." Gaziantep evlenme âdetleri alınan göçlerle birlikte hızla değişmeye ve sadeleşmeye gitmiştir. Bu durum geleneklerin yeni nesile aktarımını da engellemektedir (Yetkin, 1964, s. 33).

Erol Güneyligil “Gaziantep Folklor Yaşantısı” (1968, s. 135) başlıklı yazısında Gaziantep’teki evlenme âdetlerini "kız isteme, nişan, yatak biçme, kadın ve erkek kınası, düğün, gelinci, yanıt" şeklinde sıralar. Geçmişte Gaziantep halk kültüründe bu süreçler içerisinde ebeveynlerin etkin rolü bulunmaktaydı (Korkmaz, 1999, s. 92). Kız ve erkeğin birbirini görüp beğenmesine ve bu şekilde görücü gidilmesine rağmen, görücüler kızın ve ailesinin genel durumunu incelerlerdi. "Düvürcü" olarak tabir edilen bu 
görücüler, "Kız evinde yerler, içerler, kızın hizmetine, nezaketine, hatta kahve, su vermesine kadar bakar, bir şey söylemeden dönerler. Evde uzun uzadıya konuşulur, düşünülür, kızın ailesi hakkında malumat alınır ve beğenilirse karar verilir" (Sadık, 1931, s. 53) daha sonra kız istenmeye gidilirdi.

Makalenin konusunu teşkil eden Gaziantep’te yataküstü geleneği, diğer evlenme âdetleri gibi zaman, şekil ve içerik olarak değişiklikler gösterse de sosyo-ekonomik ve kültürel işlevlerini korumuştur. Bu gelenek yörede "yatak biçme" olarak da bilinmektedir. Eskiden gelin ve damadın evine konulacak olan yatakların tamamı evde yapılmaktaydı. Döşek, yorgan ve yastık gibi eşyaların hazırlanması için yün alınır ya da varsa hayvanlardan kırpılırdı. Daha sonra bu yünün yıkanması da kendi içerisinde bir yardımlaşma ve eğlence vesilesine dönüşürdü. Yünleri yıkamak üzere köylerde, pınar başlarında, merkezde ise Alleben Deresi'ne gidilirdi. İmece usulü dost, akraba, mahalleli (kadınlar) toplanarak yünler yıkanırdı. Yünler yıkanırken de maniler söylenip oyunlar oynanarak eğlenilirdi. Bugün yün yıkama geleneği ortadan kalkmış olup genellikle fabrikasyon ürünler, hazır yatak ve yorganlar kullanılmaktadır (Konut, 2012, s. 53).

Eskiden yün yıkama uygulamasının ardından yatak biçme günü belirlenir ve yine kadınların katıldığ1 bir eğlence törenine dönüşürdü. Kız ve erkek tarafinın yakın akrabalarının ve diğer aile çevresinin kız evinde toplandığı bu gün de oğlan evi tarafindan daha önceden alınmış ve kızın evine gönderilmiş olan yatak, yorgan ve yastıkların kumaşları ile döşek ve yorgan yüzleri (kılıflar) iyi dileklerle dikilerek hazırlanır. Bu sırada zılgıtlar çalınır, dualar edilir, gençler oynar eğlenir. Bugün içerisinde yeme içme masrafları da erkek tarafınca karşılanmaktadır. Böylece kız evi ve oğlan evi arasında yardımlaşma sağlanmaktadır (Yener, 1947a, s. 15; Köylüoğlu, 2004, s. 91; Tokuz, 2004, s. 180).

Yatak biçme geleneği aynı zamanda hediyeleşmeyi de içeren bir uygulamadır. Hazırlanan çeyizin eksiklikleri akrabalar ve diğer davetliler tarafindan getirilir. İmece usulüyle yapilan yatak biçme gününde "yatak, cüdele, döşek, şilte, minder, yastık gibi eşyalar kız ve oğlan evinden gelen kadınlarla özenle hazırlanır ve kızın çeyizine konulur. Eskiden bu eşyalar deftere yazılır; buna çeyiz defteri ya da çeyiz cüzdanı denilirdi. Buradaki amaç herhangi bir anlaşmazlık çıkarsa bu deftere ya da cüzdana başvurmaktı. Ancak bugün böyle bir uygulama pek kalmamıştır. Yatak biçme genellikle perşembe günü yapılmaktaydı.” (Kutlu, 2011, s. 62). Yatak biçme gününde tutulan çeyiz defteri uygulaması işlevi değişerek devam etmektedir. Bu deftere getirilen hediyeler kaydedilmekte, hediyelerin unutulmaması ve karşllğı̆nın geri götürülmesine özen gösterilmektedir.

Çeyiz hazırllkları bittikten sonra düğünden bir hafta önce pazar gününe denk gelecek şekilde çeyiz, bir törenle oğlan evine götürülür. Araçlara yüklenen çeyiz eşyaları şehrin ana caddelerinde dolaştırılarak davulzurna eşliğinde oğlan evinin önüne getirilir. Çeyiz getirme alayları şatafatlı törenlerdir (Özmen, 1944, s. 19; Apaydin, 1960, s. 58).

Sosyo-kültürel ve ekonomik değişmelerle birlikte yün yıkama ve yatak biçme geleneği, büyük oranda yok olmuştur. Ancak, bu gelenekler etrafındaki gelişen işlevlerin benzer törenler içerisinde varlığını sürdüğü görülmektedir. Yatak biç̧me geleneği, yataküstü geleneğine dönüşmüştür. Bugünde de kısmen çeyizle ilgili hazırlıklar yapılmakla birlikte yataküstü, daha ziyade hazırlanan çeyizin çağrılan misafirlere sergilendiği bir tören mahiyetindedir. Geçmişte olduğu gibi eğlence, sosyal dayanışma ve ekonomik paylaşım işlevleri yataküstü töreni içerisinde devam etmektedir.

Gaziantep evlenme gelenekleri içerisindeki yataküstü geleneği, sosyo-kültürel ve ekonomik hayata paralel olarak değişmiştir. Çalışmanın veri toplama aşamasında kaynak kişilerden alınan bilgiler bu değişim sürecini yansıtacak şekilde farklılık göstermektedir. Gaziantep'te düğünden bir hafta önce çeyiz, tören eşliğinde gelin ve damadın yaşayacakları eve getirilir. Düğün hazırlıkları sırasında çeyiz götürülmeden önce hazırlanan eşyalar, belirlenen bir günde kız evine çağrılan misafirlere sergilenir. Akrabalar, komşular ve diğer tanıdıklar bu törene katılır. Misafirler hediyeleriyle birlikte gelerek çeyizlere bakarlar (KK1, KK 2, KK 3, KK 4, KK 5).

Bu tören çeyizin gelin ve damadın kalacakları eve götürülmeden üç dört gün önce yapılır. Kız evinde uygun yerlere çarşaflar asılarak üzerine nakışlar iğnelenir. Gelen misafirler çeyiz için neler hazırlandığını görür. Yatak, yorgan vb. eşyalar da uygun yerele dizilir (KK 6, KK 7). Çeyiz öncesi yapılan bu törenin amacı evlenen çifte ve ailelerine bir nevi destek olmak ve çeyizlerine katkıda bulunmaktır. Bir taraftan da kızın ve ailesinin hünerleri sergilenmektedir (KK 8). 
Yataküstü kelimesi doğrudan hediyeleşme geleneği için de kullanıllır. Ödünç sözü yörede "öndüç" şeklinde kullanılır ve bir kı evleneceği zaman çeyizi gitmeden önce, çevrenin getirdiği öndüçlü (yani karşılıklı olarak getirilen eşya, para, çanak, vs.) hediye veya gelinin eksik olan eşyasının alınıp verilmesi geleneğinde yataküstü denilir. Çeyizin tamamlanarak akraba ve tanıdıkların bir arada olması amaçlanır. Kız evinde bu gün için hazırlıklar büyük bir özenle yapılır (KK 9, KK 10, KK 11, KK 12, KK 13, KK 14). Kaynak kişilerin bir kısmı yatak üstü töreninin doğrudan düğün hazırlıkları sırasında ev araç gereçleri ve maddi ihtiyacın karşılanması adına yapılan bir çeşit organizasyon olarak ifade etmiştir. Bu organizasyona genelde yakın çevre, komşu ve akrabalar çağrilmaktadır (KK 15, KK 16, KK 17, KK 18).

Geleneksel kültürde yataküstü, öncesinde alınıp yıkanan yünlerden yeni evlenenler için yorgan, döşek ve yastık gibi eşyaların elbirliğiyle hazırlandığı gündür. Değişen sosyo-ekonomik şartlarla birlikte bu eşyalar fabrikasyon ürünlerden hazır olarak da alınmaya başlanmıştır. Bu durumda da yatak ve yorganlar için erkek tarafinca alınan yeni yüzler ve nevresimler çağrılan misafirlerle birlikte hazırlanmaktadır. Bu açıdan gelenek hızla değişmektedir (KK 20, KK 21).

Kaynak kişilerin tamamı yataküstünün kız evinde yapıldığını belirtmiştir. Kız evi tabiri yörede gelinin ailesinin evi için kullanılmaktadır. Yataküstü, gelinin, yani kızın ailesinin evinde tüm çeyizler toplandığı ve çeyiz kız evinden çıktığı için burada yapılır. Çeyiz demek gelin demektir, o yüzden kız evinde yapılmaktadır (KK 8, KK 9). Eğer ev bahçeli ise mevsime göre evin bahçesinde toplanılır. Eskiden misafirler geldiğinde dikiş makinası açılıp dikilecek şeyler hazırlanırdı (KK 20, KK 23).

Yataküstüne çağrılacak misafirler için gelin olacak kızın annesi, dolaşarak davetlilere tek tek haber verir. Ulaşım ve iletişim imkânlarının artması, sosyo-ekonomik yapıdaki değişmeler de nişan ve dügün törenlerde olduğu gibi, yataküstüne davet biçimi de birtakım değişimlere uğramıştır. Bugün davet telefon vasitasiyla da yapilabilmektedir (KK 4, KK 5, KK 11, KK 12, KK 13, KK 14). Ayrica davetiye bastırılmamaktadır. Yakın mesafede olan akraba ve diğer tanıdıkları kızın annesi dolaşıp sözlü olarak çăğrmaktadır. Eskiden mahallede ekonomik durumu iyi olmayan bir kadın "okuyucu" diye tutulurdu. Onlara para, bulgur, simit vb. verilirdi. Onlar gelecek olan misafirleri çağırırdı (KK 7).

Yataküstü geleneğinde eş-dost, akraba davet edilirken davetiye olarak şeker, çikolata, lokum, tatlı gibi güzel ve hoş olan ağız tatlandırıcı şeyler dağıtılır. Yataküstünün hangi gün, hangi saat olacağı davet edilenlerin evlerine gidildiğinde söylenir. Yani davetiye yerine eş-dost, akrabanın evine gidilir ve onları görmekten memnun olunacağ söylenir. Bizim şu gün, şu saatte yatak üstümüz var buyurun gelin, bekleriz, denilir (KK 9, KK 8, KK 10). Ayrıca yataküstünde amaç maddi eksiklikleri tamamlamak olduğundan, davetiyeye ek bir masraf yapılmaz. Bunun yerine iletişim araçları kullanılarak ve eş-dosta çikolata dağıtılarak davet yapilir (KK 15, KK 16, KK 17, KK 18).

Yataküstü kadınlar arasında yapılan bir törendir. Erkekler törene çağrılmaz ve evdeki erkekler de katılamaz. Yalnızca o gün için yapılan hazırlıklar içerisinde yer alıllar. Dışardan gelecek olan yiyecek içecekle ilgili işleri yapabilirler. Kadınlar arasında yapılan bu törende çeyiz, gelen misafirlere sergilenir. Hatta erkek tarafının kıza aldığı altınlar, kıyafetler, eşyalar da gösterilir. Törene erkekler katılamadığı gibi damat da katılamaz. Erkek tarafindan da genellikle kadınlar katılır (erkeğin annesi, ablası, teyzesi, halası, yengesi, kuzenleri vs.). Bu törene bazen kızın ve erkeğin dedeleri katılabilir. Onlar da kadınlarla aynı ortamda bulunmaz evin uygun bir yerinde olurlar (KK 8, KK 9, KK 24).

Yataküstü töreninde nelerin yapıldığıyla ilgili sorulara kaynak kişiler farklı cevaplar vermişlerdir. Bu durum, geleneğin değişim süreci ve hızıyla ilgilidir. Yatakların hazırlanıp dikildiği yatak biçme geleneğinin değişmesiyle birlikte, yataküstü genellikle hazırlanan çeyizin sergilendiği güne dönüşmüştür. Çarşaflara ve bazı yerlerde iğnelerle tutturulan nakışlar ve diğer el işleri bugün içerisinde gelen misafirlere sergilenmektedir. Mutfak eşyaları da bugün sergilenen çeyizlikler arasındadır. Eskiden bakır eşyalar odaya dizilerek gösterilirdi (KK 4, KK 5, KK 6).

Yataküstünde önce kız evine gidilir, sohbet edilerek hal hatır sorulur. Daha sonra hazırlanan yemekler sunulur ve yenilir. Misafirlerin getirdikleri hediyeler açilır. Misafirler, "Hayırlı uğurlu olsun.", "Sonu gelenlerden olsun." derler. Önceden tamamıyla hazırlanmış olan çeyizler gelen misafirlere sergilenir. Çeyizlik eşyalar kırmızı kurdele ile paketlenir. Yataküstünde aynı zamanda Gaziantep yöresine ait şarkılar, türküler söylenerek oyunlar oynanır, halaylar çekilir ve zılgıt çalınır. Daha sonra yataküstü burada sona erer ve misafirler gider (KK 8, KK 9). Bazen de gelin olacak kız oturtulur ve başına bir çarşaf tutulur. Gelenler hediyelerini çarşafin üzerine atarlar (KK 25). 
Yataküstünde çeyizin olduğu odaya gelen misafirin bebekleri veya çocukları varsa onlar odaya veya eşyaların üzerine konulur. Böylece evlenecek kızın hemen çocuğu olsun istenir. Gelen hediyeler açilırken zılgttlar çalınır ve maniler okunur. Mesela, "Maşallah, maşallah sonu gelir inşallah.", "Köprüden geçtik, sütlü kahve içtik; Beylerbeyi'nin güzel gelinini de biz seçtik.", gibi sözler söylenir (KK 9). Övgü ve gelinkaynana manilerinin söylendiği de olur:

Kayalar oymak oymak

Tepsiler dolu kaymak

Her kıza nasip olmaz

Antep'e gelin olmak (KK 22)
Sofrayı açan geldi

Kaşığ seçen geldi

Çok sevinme kaynana

Kapıdan kovan geldi (KK 22)

Misafirler hediyelerini gelin olacak kıza verirler ve verirken de kıza mutlu bir yuvası olması için dua ederler (KK 10). Yataküstünde kız annesinin kıza ne kadar yatak verdiği ve neler aldığı gösterilmiş olur (KK 11, KK 12, KK 13, KK 14).

Yataküstünde yatak dikimi yapılmaz. Zaten önceden hazırlanmıştır. Yataküstü günü, çeyizlerle birlikte önceden hazırlanan dikilmiş yatak sergilenir (KK 15, KK 16, KK 17, KK 18). Köylerdeki yataküstünde ise yatak, yorgan, seccade, yastık gibi hazırlıklar yapılır. Yünler yıkanır, yorganlar doldurulur, döşekler hazırlanır, yastıklar dikilir (KK 19). Eskiden yorganları satenlerle yüzleyip üstüne nakışlı örtü, yastıklara da danteller geçirilirdi. Artık bu hazırlıklar çok nadir görülmektedir. Bunları yaptırmak isteyenler bugün çeyiz evlerine yaptırmaktadır. Sadece belirli günde toplanıp bu günün anısına eğlence düzenlenmiş olur (KK 20).

Yataküstü, kadınların kendi aralarında düzenledikleri bir eğlenceye dönüşür. Yataküstünde gelen misafirler yapılan çeyizlere baktıktan sonra müzikler açılır ve karşlıklı çiftetelli oynanır. Erkek tarafindan görümce, kaynana veya yenge oynamaya başlar ve manilerle birlikte zılgıtlar çalınır. Sonra gelinle birlikte kaynana karşılıklı oynar (KK 3, KK 5, KK 8). Bazen de yataküstünde çeyize bakılmadan önce ve sonra halaylar çekilir, karşlıklı birçok oyun havası ile oynanır. Daha sonra gelin ve kaynanaya karşlıklı maniler düzülür ve kaynana o sırada gelinin ağzına şeker verir. Bunun nedeni gelini ile bir ömür aralarının tatlı ve huzurlu kalmasının istenmesidir (KK 9, KK 10). Kadınlar çalıp oynarlar. Eskiden sesi güzel kızlar şarkı, türkü söyler, darbuka ya da def çalardı. Şimdiyse müzik sistemi kurulup istenilen şarkılar çalınıp oynanmaktadır (KK 11, KK 12, KK 13, KK 14, KK 19, KK 20, KK 21).

Yataküstünde misafirler için hazırlanan yemekler, yörenin mutfak kültürünü yansıtmaktadır. Yemeklerin masrafı büyük oranda erkek tarafinca karşılanmaktadır. Ev yemekleri ya da firın yemekleri hazırlanabilmektedir. Firın yemeği olduğunda erkek tarafı yemekleri firında hazırlatıp getirmektedir. Ev yemekleri hazırlanırken de yemeklerin malzemeleri damadın annesi ya da diğer yakınları tarafindan önceden alınarak kız evine götürülmektedir. Bazen de firın yemekleri oğlan evi tarafindan ev yemekleri kız evi tarafindan hazırlanır. Böylece ekonomik olarak dayanışma sağlanmış olur. Hazırlanan yemekler, mevsime, gelecek olan kalabalığa ve ailelerin ekonomik durumuna göre değişebilmektedir. Hazırlanan yemekler lahmacun, patlıcan kebab1, soğan kebab1, tepsi kebab1, patates tavası gibi firın yemekleri ile dolma, doğrama, bulgur pilavı, yuvarlama, yoğurtlu patates, fasulye, tarhana çorbası, şiveydiz, kabak ekşilisi, patates cıvığı, içli köfte gibi ev yemekleridir. Ayrıca meyve ve meşrubat da ikram edilir. Yataküstünün bu faslında da şenlik havası hâkimdir. Gelen misafirlerin aç gitmemesi için özen gösterilir. Bu yüzden yapılan yemeklerin miktarında gösterişe de önem verilir (KK 1, KK 2, KK 7, KK 8, KK 9, KK 12, KK 19, KK 22, KK 23).

Yataküstü geleneğinin en önemli işlevi sosyal ve ekonomik dayanışmadır. Kaynak kişiler törenin bu yönünü özellikle vurgulamışlardır. Bu güne özel getirilen hediyeler karşıllklllık ilkesine uygun olarak hazırlanmaktadır. Getirilen hediyeler, geleneğin geçmişten bu güne geçirdiği değişiklerle birlikte çeșitlenmiștir. Eskiden yataküstüne gelinin çeyizini tamamlayacak mutfak eșyaları ağırllklı olarak getirilirdi. Bakır, kap kacak, sini, tepsi, köfte leğeni, çanak ve diğer eşyalar çeyizin eksikliklerini tamamlardı (KK 1, KK 2, KK 5, KK 7).

Bazen de yataküstüne gelen misafirler içinden gelen ve istedikleri eşya, halı, tabak-bıçak takımı, havlu, elektrikli ev eşyası, para, altın ya da öndüçlerini (ödünç), yani daha önce götürülmüşs olan hediyenin getirirler. Karşıllk getirme olduğu gibi, içten gelerek getirilen eşyaların alınması da söz konusudur. Ayrıca önceden kızın annesine sorularak eksik olan eşyalar getirilebilmektedir (KK 8, KK 9, KK 10). Kızın 
annesi, misafirleri ilk davet etmeye başladığında ona çeyizin ne eksiği var diye sorulur. Bir eksiği yok denilirse yataküstüne eşya yerine para veya altın da götürülebilir (KK 11, KK 12, KK 13, KK 14).

Yataküstüne götürülen hediyelerde bir sınır yoktur. Bu yüklü bir miktar para, altın ya da herhangi bir mutfak ve ev eşyası da olabilir. Eskiden yatak yüzü, döşek yüzü, döşeğin içine konulan yün götürülürken artık bunlara gerek kalmamıştır (KK15, KK16, KK17, KK18). Alınan eşyalar zaman içerisinde değişiklik de göstermektedir. Eskiden dikiş makinası alınırken bugün kahve makinası, çay makinası, mutfak robotu gibi elektronik eşyalar alınmaktadır (KK19, KK 20).

Alınan hediyelerde bir diğer ölçüt de akrabalık ilişkisidir. Gelinin yakın akrabaları çeyizin önemli eksiklerini alırlar. Bunlar önceden sorulur ve söylenir. Bu hediyelerin ekonomik değeri daha yüksektir (KK 21, KK 22, KK 24). Böylece yakın akrabalar arası yardımlaşma daha fazla olmuş olur.. Burada da yine karşılıklılık ilkesi vardır. Akrabalık derecesi arttıkça getirilen hediye isteğe ve tercihe bağlıdır.

Yataküstüne gelecek hediyenin ne olması gerektiği de yakın akrabalara söylenebilir. Birinci dereceden akrabalardan doğrudan eksik olan istenebilir. Davet etmeye gidildiğinde kişi genellikle, "Eksik bir şeyiniz var mı onu getireyim." der. Eğer eksik olan bir eşya varsa söylenebilir ve o getirilebilir. Davet edilirken gelecek kişiden doğrudan bir şey istenmesi ayıplanır (KK 8, KK 11, KK 12, KK 13, KK 14). Bazen de doğrudan, "Bizde şu eşya eksik bunu alırsanız, ben de senin kızında/oğlunda aynısını alır gelirim." denilebilir (KK 9).

Kaynak kişilerden bir kısmı yataküstü geleneğinin zaten bir istek üzerine kurulu olduğunu belirtmişlerdir. Buna göre davet edilen kişinin sorması gerekir. Evlenecek olan kişinin ne ihtiyacı varsa annesi davetlileri çağıırırken hediye isteğini de belirtebilir. Çünkü yataküstü bir tür yardımlaşma ve dayanışma organizasyonudur. O yüzden hediyeyi özel olarak belirtmek ayıp değildir (KK 15, KK 16, KK 17, KK 18).

Yataküstü geleneğinde sosyo-ekonomik dayanışma yakın akrabalar arasında daha fazladır. Kaynak kişiler bu konuda tutarlı cevaplar vermiştir. Amca, dayı, teyze ve hala gibi akrabalar, çeyizin hazırlık sürecinde daha fazla katkıda bulunabilir (KK 2, KK 3, KK 4, KK 8, KK 19). Getirilen hediyenin ekonomik değerinde bir diğer belirleyici etken karşılıkllıktır. KK 9 bu konuda şu cevabı vermiştir: "Hediyenin büyüklüğü akraba ve yakınlğga göre değişir. Çünkü çok yakın olduğumuz ve iç içe olduğumuz yakınlarımıza daha büyük ve değerli hediyeler götürürüz. Bizde bu durum, yani daha büyük hediye götürme işi, biraz da karşı tarafın sana getirdiği hediyeyle ilgilidir. Yani karşı taraf büyük bir şey getirdiyse eğer bizde ona o güzel ve büyük hediyesinden dolayı daha büyük bir hediye götürürüz.” Yakın akrabalar yataküstüne değerli bir hediyeyle katılmadığında aileler arasında küslük olduğu veya husumet olduğu düşünülür (KK 11, KK 12, KK 13, KK 14). Toplumun beklentisi de çeyizdeki eksiklikler için yakın akrabaların daha fazla katkı yapmasıdır. Aksi durum ayıplanır (KK 6). Bu durum geleneğin sosyal paylaşımı ve yardımlaşmayı dayatmasıyla ilgilidir. Gelenek dairesine girmeyen ve verilen rolü yerine getirmeyen kişilerin toplum içerisindeki konumu sarsılır.

Görüşülen yirmi beş kaynak kişinin tamamı yataküstüne götürülen hediyenin mütekabiliyet ya da karşılıklılık ilkesine göre götürüldüğü yönünde cevaplar vermiştir. Yöre ağzında yukarıda da ifade edildiği gibi, ödünç kelimesi, öndüç şeklinde kullanılmaktadır. Dügün, çeyiz, doğum, yas yeri gibi kutlama, ziyaret ve taziye amaciyla götürülen hediyeler hem götüren hem de hediyeyi alan açsindan öndüç olarak görülmektedir. Yataküstü geleneğinde götürülen hediyeler de bu kapsamdadır. Getirilen hediye için "Ben de öndücü var.", "Öndüç götürme." veya "Öndücümü getirdi." gibi ifadeleri kullanılır (KK 1, KK 22, KK 23, KK 24). Getirilen hediye için kullanılan bir diğer ifade de "Bende yükü var." şeklindedir (KK 4). Getirilen hediye, o hediyeyi alan için geri götürülmesi gereken bir yüktür.

Yataküstüne götürülen eşya, altın ve para getiren kişi tarafindan karşllıklı olduğu dile getirilmez. Ancak getiren kişinin bir düğünü veya merasimi olduğu zaman aynı şekilde getirdiği kişi de ona götürür. Getiren kişi karşılıklı olduğunu söylemese de getirdiği kişi onun karşlloğını götürmesi gerektiğini bilir. Çünkü yataküstü töreni, bir nevi eksik olanı tamamlama ve destek olmak amaçlı yapılan bir uygulamadır. Aynı zamanda unutulmaması için deftere de kimin ne getirdiği yazılır. Hediye götürülürken de gelenden daha fazlası götürülmeye çalışılır (KK, 5, KK 8, KK 9, KK 10). Kaynak kişilerin bir kısmı bunun doğrudan bir yardımlaşma organizasyonu olduğu için her şeyin kayıt altına alındığını belirtmiştir (KK 15, KK 16, KK 17, KK 18). Kayit altına alma eskiden beri değişmeyen uygulamalardan birisidir. Bu tutulan defter üzerinden gelen hediyeye ne karşlık götürüleceği takip edilir. Bu deftere çeyiz defteri denilir (KK 
19, KK 20, KK 22, KK 23, KK 24). Bu durum geleneğin geçmişten bugüne yardımlaşma ve dayanışma işlevinin karşıllklılık illkesine göre devam ettiğini göstermektedir.

Yataküstüne getirilen hediyenin öndücünün götürülmesi için karşı tarafının oğlunun ya da kızının evlenmesi beklendiği gibi, evlenecek çocuğu olmayanların diğer önemli günleri takip edilir. Bu günler, doğum ve ölüm gibi geçiş törenleri olabildiği gibi; hasta ziyareti, yeni bir ev ya da araba alma durumunda hayırlı olsun ziyareti de olabilir. Cenaze sonrası taziye için yas yerine gidilirken daha önce gelen hediyenin ekonomik değerine uygun bir şey götürülmeye dikkat edilir. Yörede "gelen hediyenin altında kalmamak" anlayışı yaygındır (KK, 2, KK 3, KK 6, KK 8, KK 9, KK 21). Buradan hareketle, yataküstü geleneğinin sosyal paylaşım ve dayanışma için bir araç olduğu söylenebilir. Bu paylaşım modeli farklı vesilelerle karşılıklılık ilkesinin yerine getirilmesi kaydıyla devam etmektedir.

Yataküstüne getirilen hediyenin karşllığ uygun şartlar oluştuğunda mutlaka götürülmek zorundadır. $\mathrm{Bu}$ ilkenin uygulanması bir sosyal baskı şeklinde olabildiği gibi, hediye götüren kişinin götürdüğü hediyeyi bizzat istemesi şeklinde de olabilmektedir. Kendi özel günü olan kişi götürdüğü hediyelerin karş1llğının gelip gelmediğini kontrol eder. Gelmediği takdirde getirmeyenlerin duyacağı şekilde tanıdıklar vasıtasıyla haber gönderir (KK 4). Bunun için yörede "adamlık etmek" tabiri de kullanılır. Hediyesinin karşıllğını bekleyen kişi "Benim onda adamlı̆̆ım var." der. Hediye geri gelmezse "O benim adamlığımın altında kaldı.” denilerek küsülür (KK 7).

Yataküstüne götürülen veya getirilen hediyenin karşıllğ̣ fazla olmalı ancak eksik olmamalıdır. Çünkü getiren kişi seni saymış getirmiştir, senin de onun karşıllğında aynısını ya da fazlasını yapman en doğrusudur, anlayışı yörede hâkimdir. Hediyeyi getiren kişinin çocuğu evlenirken getiren kişi, aynı hediye ya da aynı değerde olan bir hediyeyi karşıllk olarak bekler. Eğer götürülmezse bir şekilde bu durum o kişiye duyurulur. Çünkü bu hediye de zaten karşl1ılılık âdettir (KK 8, KK 9, KK 10). Kaynak kişilerin bir kısmı hediyeleşmenin bir çeşit yatırım olduğunu belirtmiştir. Özellikle ihtiyaç hâsıl olduğunda karşıllı̆̆ getirilmeyen hediye geri istenmektedir. Bu durumlar söz konusu olmadığında yalnızca durum tanıdıklar vasıtasıyla dillendirilir ve o kişi ayıplanır (KK 11, KK 12, KK 13, KK 14). Bazen de hediyenin karşıllı̆̆ gelmediğinde bir sonraki çocuk evlendirilirken o kişi davet edilir ve hediye istenir. Götürülen hediyenin mutlaka kız çocuk evlendirilirken getirilmesine gerek yoktur; erkek çocuk evlendirilirken de düğun öncesinde uygun bir hediye getirilebilir (KK 15, KK 16, KK 17, KK 18, KK 22, KK 24).

Yataküstü töreni, evlenme gelenekleri içerisindeki dayanışma ve yardımlaşma modellerinden birisidir. Dügünden bir hafta önce çeyizin gelin ve damadın kalacağı eve getirilmesinden önce eksiklerinin tamamlanması için yapılmaktadır. Akrabalar ve diğer tanıdıklar bu sürece dâhil olurlar. Çalışmanın odak noktasını teşkil eden sosyo-ekonomik paylaşım ve dayanışma, yataküstü töreninin temelini oluşturmaktadır. Bununla birlikte gelenek çevresinde oluşan uygulamaların çok yönlü işlevleri bulunmaktadır. W. Bascom, folklorun işlevlerini (2010, s. 71-86), "boş̧a vakit geçirme, eğlenme ve eğlendirme; değerlere, toplum kurumlarna ve törenlere destek verme; eğitim veya kültürün genc kuşaklara aktarlmasi; toplumsal ve kişisel baskelardan kurtulma" şeklinde sıralamaktadır. Bir folklor olayı olarak yataküstü töreni, söz konusu işlevlerin belirli ölçülerde gerçekleştiği bir alandır. Yataküstü, kadınların kendi aralarında düzenledikleri ve çeşitli müzik ve oyun unsurlarını da barındıran bir gelenektir. Bu bakımından eğlenme, eğlendirme ve iyi vakit geçirme işlevi bulunmaktadır. Kadınların kendi aralarında şarkı-türkü söyledikleri, mani okudukları ve elektronik müzik aletleri eşliğinde oynadıkları bir ev içi eğlencesidir. Bir folklor olayı olarak yataküstünün bu çalışmada dikkat çekilen en önemli özelliği, değerlere, toplum kurumlarna ve törenlere destek verme işlevidir. Sosyal dayanışma ve ekonomik paylaşım modeli olarak yataküstü töreni, toplumsal yapının korunmasına ve devamlılığına katkı sağlamaktadır. Evlilik kurumunun şekillenmesinin temelinde ekonomik şartların sağlanması yatmaktadır. Yataküstü geleneği etrafındaki yardımlaşma modeli, bu sürece açık destek sağlamaktadır. Özellikle geleneksel toplum yapısı içerisinde bu yardımlaşma biçimi karşılıklılık ilkesiyle işlemektedir. Bu çerçevede bir ekonomik döngü sağlanmakta ve sosyal bağlar canlı tutulmaktadır. Bu süreç yalnızca akrabalar arasında değil, kentleşmeyle birlikte kurulan yeni sosyal çevreyi de içine almaktadır. Dügün öncesi yapılan yataküstü töreni, dügünün sosyo-ekonomik alt yapısını hazırlamakta ve şekillenmesine katkı yapmaktadır. Her folklor olayı katılımcıları ve izleyici-dinleyicileri için aynı zamanda bir kültürel eğitim alanıdır. Bu bağlamda yörede çeyizin henüz erken yaştan itibaren hazırlık süreci, nakış, örgü, çeşitli el işleri, ev araç gereçleriyle birlikte, aynı zamanda bir somut olmayan kültürel miras alanı olduğu söylenebilir. Yataküstü geleneğinde çeyiz için hazırlanan ürünlerin sergilenmesi hüner ve itibar göstergesidir. Böylece bu ürünlerin yapımının öğrenilmesi de teşvik edilmektedir. Yataküstüne katılan misafirler, aynı zamanda geleneksel sözlü kültürün de icrasına katkıda bulunmaktadır. Kadınlar arasındaki 
bu törende her yaş grubundan insan bulunabilmektedir. Böylece tören, çeşitli hüner ve becerilerle birlikte yardımlaşma kültürünü de içeren bir değerler aktarım alanına dönüşmektedir. "Toplumların ekonomik ve kültürel göstergesi kabul edilen, birlik-beraberlik ve sosyal dayanışmanın örneği olan çeyiz, hala ilerleyen zamana göre bazı değişikliklere uğrasa da geçmişte olduğu gibi genç kızların heyecanlarını, umutlarını, tasarım güçlerini hünerleriyle çeyiz eşyalarına aktarmaları onların varlığını sessiz ama etkili bir biçimde ortaya koymaktadır." (Öğüt-Eker, 1998, s. 154).

Gündelik hayatın rutininden çıarak kadınlar arasında yapılan ev toplantısına dönüssen yataküstü geleneği kültürel bir mikro alan teşkil etmektedir. Bu alana dâhil olan insanlar, törensel üretim ve tüketim döngüsüne girmektedir. Bir yandan grup içerisinde geleneğe dâhil olarak rahatlama sağlanırken bir yandan da eğlence esnasındaki oyunlarla, kendini bedensel ve sözlü ifade ortamı bulunmaktadır. Böylece bu tören katılıcılarına gündelik hayattaki kendini ifadeyi zorlaştıran toplumsal baskılardan sıyrılarak rahatlama alanı sağlamaktadır.

Hayatın geçiş dönemleri etrafindaki törenler, "insan hayatına yeni bir şekil, enerji, dinamizm, davranış ve yaşama tarzı" (Kaya, 1996, s. 23) kazandırır. Düğünü bu törenler içerisinde en kompleks yapiya sahip olan geçiş törenidir. Çeşitli törenler, sosyo-ekonomik paylaşım ve yardımlaşma modelleri ile somut ve somut olmayan kültürel miras birikimi, düğün etrafinda birikmiştir. Eski kültürlerden bugüne, bu törenlerde aileler ve diğer sosyal çevre "zorunlu armağan değişimine" (Tezcan, 2008, s. 57) başvururlar. Türkiye'deki evlilik gelenekleri etrafinda şekillenen hediyeleşme geleneğini törensel tüketim alanı olarak değerlendiren Ceyda Durutürk (2008, s. 43) konuyla ilgili şu tespitleri yapmıştır:

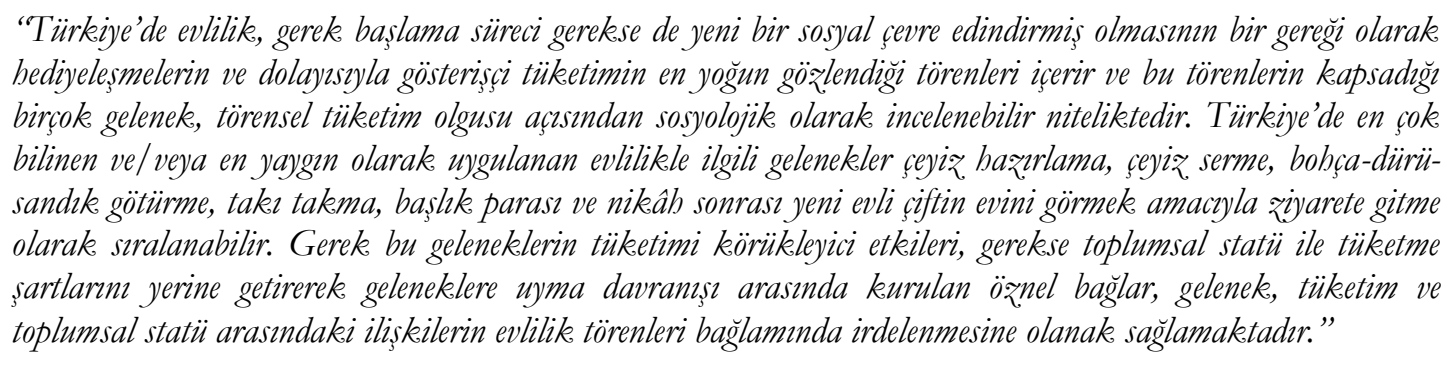

Türk kültüründe evlilik gelenekleri etrafindaki sosyal dayanısma ve ekonomik paylaşım modelleri geleneğin değişim süreçleriyle birlikte güncellenmiştir. Tarım toplumunda düğünün zamanı, ekonomik şartlara bağlı olarak hasat dönemlerine göre belirlenmektedir. Düğünde, "ekonomik durumla ilintili olarak belirli bir gelirin de elde edilmesi” (Tokuz, 2020, s. 90) hedeflenmiştir. Böylece düğ̈nün ekonomik boyutu yardımlaşma yoluyla aşılmaya çalışılmışır. Bugün de benzer beklentilerle birlikte, kent ortamında dügün için herhangi bir zaman dilimi belirlense de tarım ekonomisinin etkileri de devam etmektedir.

\section{Sonuç}

20. yüzyıldan itibaren ulaşım ve iletişim imkânlarının hızlı gelişimi, sosyal ve kültürel hayatı yakından etkilemiştir. Özellikle kentleşme ve elektronik kültür ortamı, dar sosyal çevredeki geleneksel uygulamaların yok olmasina veya değişmesine neden olmuştur. Hayatın geçiş dönemleri olan doğum, evlenme ve ölüm etrafındaki inanış ve uygulamalar, bu çerçevede ele alınması gereken önemli örneklerdir. Geleneğin dinamik yapısına uygun olarak yeni şart ve çevre içerisinde geçiş dönemi âdetlerinin işlevlerini koruyarak varlı̆̆ını sürdürdüğü söylenebilir. Hayatın üç temel geçiş döneminden birisi olan evlenme, Türk kültüründe geçmişten bugüne pek çok töreni barındıran ve içerisinde halk inanışı ve uygulama zinciri bulunan bir yapıya sahiptir.

Evlenme, toplumun kolektif katılımını gerektiren bir sosyal dayanışma ve paylaşım alanıdır. Bu çerçevede makalede Gaziantep evlenme gelenekleri içerisinde bulunan yataküstü töreni, bir dayanışma ve paylaşım modeli olarak ele alınmıştır. Yataküstü töreni, yörede çeyizüstü olarak da bilinmektedir. Gaziantep halk kültüründe çeyiz, dügünden bir hafta önce davul zurna eşliğinde bir törenle kız evinden alınarak gelin ve damadın yaşayacakları eve götürülmektedir. Çeyiz götürülme töreninden önceki hafta içerisinde belirlenen bir günde, bu gün genellikle perşembe olmaktadır, yataküstü töreni yapılmaktadır. Yataküstü, davetli misafirlere çeyizin sergilendiği ve gelenlerin çeyizin eksiklerini tamamlayacak hediye getirdikleri bir törendir. Kız evinde yapılan yataküstü törenine yalnızca kadınlar katılabilmektedir. Törene kız ve erkek tarafi davet edilebilmektedir. Yataküstü töreni kadınlar arasında bir evi içi eğlencesine dönüşerek şark1 ve türkülerin söylendiği, müzik eşliğinde oynandığı, övgü ve gelin-kaynana manilerinin 
söylendiği, bugüne özel yöresel yemeklerin hazırlandığı bir gündür. Yataküstü töreninin masraflarını büyük oranda erkek tarafı karşılamaktadır. Böylece aileler arasında ekonomik dayanışma da sağlanmaktadır.

Makalede, "öndüç hediye" uygulamasının bir evlenme geleneği olan yataküstü töreni içerisinde sosyoekonomik paylaşım ve kültürel aktarım alanı oluşturması incelenmiştir. Gaziantep’te yataküstü törenine çağrilan kişiler, mutlaka hediye alarak bu törene dâhil olurlar. Alınan bu hediyede karşılıklılık ilkesi esastır. Gelen hediyeler çeyiz defterine kaydedilir ve daha sonra karşıllğı götürülür. Götürülen hediyenin, gelen hediyeden daha değerli olması bir itibar göstergesidir. Götürülen hediyenin karşıllğının gelmemesi toplum tarafından ayıplanmaktadır. Yataküstüne götürülen hediyenin mahiyeti, akrabalık derecesine göre değişmektedir. Yakın akrabalar, çeyizin eksikliklerinin tamamlanabilmesi için ihtiyaca göre daha değerli hediyeler götürebilmektedir.

Eksi kültürlerden bugüne törenler, aynı zamanda bir toplumsal iletişim ve tüketim alanı olarak kültürel hayatı şekillendirir. Toplumsal törenler, toplumun anımsama ve geleceğin inşa edilme biçimlerinden birisidir. $\mathrm{Bu}$ alanlarda topluluk, sosyal dayanışma ve ekonomik paylaşımda bulunarak varlı̆̆ını korur. Bu çerçevede makalede Gaziantep evlenme gelenekleri içerisindeki yataküstü töreninin öndüç hediye uygulamasıyla birlikte yardımlaşma, dayanışma ve kültürel aktarım işlevlerine sahip olduğu sonucuna varılmıştır.

\section{Etik Beyan}

“Öndür Hediye: Gaziantep’te Yataküstü Geleneği ve İslevleri” başlıklı çalışmanın yazım sürecinde bilimsel kurallara, etik ve alıntı kurallarına uyulmuş; toplanan veriler üzerinde herhangi bir tahrifat yapılmamış ve bu çalışma herhangi başka bir akademik yayın ortamına değerlendirme için gönderilmemiştir. $\mathrm{Bu}$ araştırmada doküman incelemesi yapıldığından etik kurul kararı zorunluluğu bulunmamaktadır.

\section{Kaynakça}

Apaydın, U. (1960). Gaziantep’te cehiz (cihaz) töreni. Gaziantep Kültür Dergisi, 3(27), 58.

Bakırcı, N. (2019). Dede Korkut Kitabı bağlamında Oğuzlarda toy geleneği. Avrasya Uluslararası Araștrmalar Dergisi, 7(20), 130-142.

Bascom, W. R. (2010). Folklorun dört işlevi. (Çev. F. Çalış). M. Ö. Oğuz ve S. Gürçayır (Ed.), Halkbiliminde Kuramlar ve Yaklasimlar 2. Ankara: Geleneksel Yayıncillk.

Berber, O. (2009). Türk kültüründe eğlence ve birlik unsuru olarak düğünler. Süllyman Demirel Üniversitesi Sosyal Bilimler Enstitïsï Dergisi, 2(10), 1-11.

Boratav, P. N. (1994). 100 soruda Türk folkloru. İstanbul: Gerçek Yayınevi.

Connerton, P. (1999). Toplumlar nasl anmsar? İstanbul: Ayrıntı.

Derleme Sözlüğü (1977). Öndüç. (Cilt 9). Ankara: TDK.

Dundes, A. (1998). Halk kimdir? (Who are the folk?). (Çev. M. Ekici). Milli Folklor, 31, 139-157.

Durkheim, E. (2006). Toplumsal işbölümü. (Çev. Ö. Ozankaya). İstanbul: Cem Yayınevi.

Durutürk, C. (2008). Törensel tüketim, sınıf ve gelenek: Türkiye'deki evlilik törenlerine sosyolojik bir bakış. Edebiyat Fakiultesi Dergisi, 25(1), 37-55.

Duymaz A. (2005). Oğuz Kağan Destanı’ndan Dede Korkut’a toy geleneğinin simgesel anlamı ve Türk paylaşım modeli. Karadeniz Arastrumalar, 5, 337-60.

Düzgün. D. (1991). Geleneksel bir yardımlaşma kurumu hab. Millǐ Folklor, 11, 49-51.

Ekici, M. (2000). Halk, halk bilimi ve halk bilgisi üzerine bir deneme. Milli Folklor, 45, 2-8.

Gülensoy, T. (2007). Türkiye Türkçesindeki Türkçe sözcüklerin köken bilgisi sözlüğü I. Ankara: Türk Dil Kurumu Yayınları.

Gümüş, İ. (2019). Bir kültür ekonomisi dönüşüm serüveni: 'okuntu'dan 'e-davetiye'ye. RumeliDe Dil ve Edebiyat Arastrmalar Dergisi, 15, 227-241.

Günay, U. (1991). Folklor mahsullerinin tabiatı. Millî Folklor, 11, 9-12.

Güneyligil E. (1968) Gaziantep folklor yaşantısı. Gaziantep Kültür Dergisi, 11(136), 132-137.

İnan, A. (1998). Türk düğünlerinde exogamie izleri. Makaleler ve incelemeler I. Ankara: TTK.

Kafesoğlu, İ. (1997). Türk Millâ Kültüriü. İstanbul: Ötüken.

Karakelle, A. ve Özbağ̣, T. (2019). Somut olmayan kültürel mirasın korunması bağlamında çeyiz geleneği "Erzurum örneği”. Türkiye Sosyal Arastrmalar Dergisi, 24(3), 668-689.

Kaya, D. (1996). Dügünlerimizle ilgili terimler ve bunların fonksiyonel özellikleri. Millı̌ Folklor, 29-30, 23-29.

Konut, C. (2012). Din ve sekülerlik bağlammda eğlence kültürü: gaziantep dïgüuleri örneği (Yüksek Lisans Tezi). Kahramanmaraş Sütçü İmam Üniversitesi Sosyal Bilimler Enstitüsü, Kahramanmaraş.

Korkmaz M. K. (1999). Elli yil önceki Gaziantep'te gelin ve damat. Millı Folklor, 42, 92-95.

Köylüoğlu, A. (2009). Kadim şebir Gaziantep. İzmir: Neşa Ofset. 
Kutlu, S. S. (2011). Gaziantep geleneksel kültüründe evlenme (Yüksek Lisans Tezi). Gaziantep Üniversitesi Sosyal Bilimler Enstitüsü, Gaziantep.

Malïnowskï, B. (2016a). Bilimsel bir kültür teorisi (Çev. D. Uludağ). Ankara: Doğu Batı.

Malïnowski, B. (2016b). İptidai cemiyette cürüm ve âdetler. İstanbul Üniversitesi Sosyoloji Dergisi, 2(1), 218-249.

Mandaloğlu, M. (2012). İslamiyet’ten önce Türklerde toplantı ve törenler. TS A, 16 (2), 211-232.

Nas, E. (2018). Türk çeyiz kültürü çevresinde sözsüz iletişim dili olarak gelişen milli söz hazinesi. Turkish Studies, 13(18), 991-1005.

Naskali, E. G. (2007). Kültür taribimizde çeyiz (Edt: E. G. Naskali ve A. Koç). İstanbul: Picus Yayıncılık.

Ögel, N. (1982). Türklerde kalın ve başlık. II. Milletlerarası Türk. Folkelor Kongresi Bildirileri IV. Cilt, Gelenek, Görenek ve Inançlar (ss. 393-396). Ankara: Kültür ve Turizm Bakanlığı Milli Folklor Araştırma Dairesi Yayınları.

Öger, A. (2008). Türk kültür tarihinde Alp Er Tonga ve Uygur Türkleri arasında onunla ilgili anlatmalar. Turkish Studies, 3(7), 508-523.

Ögüt-Eker, G. (1998). Karakeçili Türk düğ̈nü. Ankara: Hacettepe Üniversitesi Sosyal Bilimler Enstitüsü.

Örnek, S. V. (2000). Türk halkbilimi. Ankara: Kültür Bakanlı̆̆ı.

Özarslan, M. (2005). Bir halk ekonomisi örneği olarak "hab” ve "değişik / denişik" geleneği ve işlevleri. Türkbilig, 10, 54-59.

Özarslan, M. ve Karataş, H. (2016). Halk ekonomisinde mübadele: “Örüden tutma kardaşlık” örneği. Millî Folklor, 28(110), 17-29.

Özdemir, N. (2008). Türk Hediyeleşme Geleneği ve Medya. Uluslararası Sosyal Aratırmalar Dergisi 1(4), 467-480.

Özmen, M. (1944). Çeyiz alay1. Basspinar Gaziantep Halk Evi Dergisi, 6(60-61), 19.

Sadık, E. (1931). Evlenme adetleri Gazi Ayıntabın cenubundaki yazı köylerinde ve seyyar Türkmenlerde. Halk Bilgisi Haberleri. 2(15), 53-56.

Sennett, R. (2012). Beraber. (Çev. İ. Özküralpli). İstanbul: Ayrıntı.

Tietze, A. (2002). Tarihi ve etimolojik Türkiye Türkesesi lugatı. Birinci Cilt, İstanbul: Simurg Kitapçllk.

Tezcan M. (1998). Türk kültüründe başlı parası geleneği (kültürel antropolojik yaklaşım). Ankara: Kültür Bakanlı̆̆ı Yayınları. Tezcan, M. (2008). Kültürel antropoloji. Ankara: Maya Akademi.

Tokuz, G. (2004). 20. yüzynlda Gað̧iantep’te eğlence hayatı. Gaziantep: Gaziantep Üniversitesi Yayını.

Tokuz, G. (2020). Beslenme kültürümüzün izleri, ulu düğün iyi düğün hoş dügün, pilavı yok boş dügün. Metro Gastro, 99, $89-100$.

Yakıc1, A. (1991). Düğün kelimesi ve kültürümüzdeki yeri üzerine. Milli Folklor, 11, 33-36.

Yener, Ş, S. (1947a, 1947). Gaziantep'te evlenme. Baspinar Gaz̧iantep Halk Evi Dergisi, Y. 8, C. 4: 87-1, s. 15-16; 87-2, s. $9-15$.

Yeşil, Y. (2014). Türk dünyasında geçis dönemi ritüelleri (doğum-evlenme-ölüm gelenekleri). Ankara: Grafiker.

Yetkin, H. (1964). Gaziantep evlenme âdetlerinden, gerdekle ilgili manzumeler. Gaz̧iantep Kültür Dergisi, 7(74), 33-34.

Yıldırım, D. (1989). Sözlü gelenek kültürü. Milli Folklor, l(1), 6-7.

Yüksekkaya, G. S. (2007). Kalın ve çeyiz. E. G. Naskali ve A. Koç (Ed.) İstanbul: Kitabevi (396-406 ss.).

\section{Kaynak Kişiler}

KK 1 Kiraz Güç, 47 yaşında, ilkokul, Gaziantep. 17.10.2020

KK 2 Meral Dağlı, 53 yaşında, ilkokul, Gaziantep. 17.10.2020

KK 3 Hatice Eksen, 53 yaşında, ilkokul. Gaziantep. 18.10.2020

KK 4 Esen Atıcı, 35 yaşında, lisans, Gaziantep. 18.10.2020

KK 5 Nuray Atıc1, 40 yaşında, lisans, Gaziantep. 18.10.2020

KK 6 Elif Neşe Atıc1, 58 yaşında, ortaokul, Gaziantep. 18.10.2020

KK 7 Gülten Eksen, 76 yaşında, ilkokul, Gaziantep. 16.10.2020

KK 8 Döndü Soytürk, 48 yaşında, ilkokul, Gaziantep.14.10.2020

KK 9 Bahar Soytürk, 20 yaşında, ilkokul, Gaziantep. 14.10.2020

KK 10 Fatma Gürsel, 40 yaşında, ilkokul, Gaziantep. 16.10.2020

KK 11 Fatma Topçu, 46 yaşında, lise, Gaziantep.11.10.2020

KK 12 Seda Kılınç, 27 yaşında, önlisans, Gaziantep.11.10.2020

KK 13 Dursun Güneş, 56 yaşında, ilkokul, Gaziantep.12.10.2020

KK 14 Zeynep Kumru, 47 yaşında,, önlisans, Gaziantep. 12.10.2020

KK 15 Türkan Sever, 48 yaşında, ilkokul, Gaziantep.02.10.2020

KK 16 Ayşe Bozkurt, 53 yaşında, okur-yazar değil, Gaziantep.02.10.2020

KK 17 Gülizar Halman, 38 yaşında, ortaokul, Gaziantep. 05.10.2020

KK 18 Selbi Kırtay, 60 yaşında, okur-yazar değil, Gaziantep.05.10.2020

KK 19 Selda Öztürk, 38 yaşında, lise, Gaziantep.09.10.2020

KK 20 Pınar Zorlar, 43 yaşında, ilkokul, Gaziantep.09.10.2020

KK 21 Ayșe Ceylan, 40 yaşında, ilkokul, Gaziantep.09.10.2020

KK 22 Kiymet Yılmaz, 50 yaşında, ilkokul, Gaziantep.01.12.2020

KK 23 Filiz Ertural, 35 yaşında, lisans, Gaziantep. 01.12.2020

KK 24 Sultan Tek, 60 yaşında, okur-yazar değil, Gaziantep.01.12.2020 
KK 25 Gonca Tokuz, 65 yaşında, yüksek lisans, Kilis (Gonca Tokuz, uzun süre Gaziantep’te yaşamış ve aynı zamanda bir halk kültürü araştırıcısıdır.) 05.12.2020

\section{EXTENDED ABSTRACT}

In traditional knowledge transfer processes, ceremonies, narratives and spaces serve as social memory carriers between generations. Beliefs and practices around birth, marriage and death, which are the transition periods of life, are among the areas where the oral culture tradition is preserved. Marriage ceremonies include practices that heavily include social solidarity and economic sharing models. The subject of the article is the yataküstü tradition and functions in Gaziantep marriage ceremonies. In the article, it is aimed to examine the gift giving form in the yataküstü tradition and evaluate the social solidarity and cultural transfer functions of this gift form. In this context, observation and interview techniques, which are among the methods of collecting folk information, were used, and a questionnaire was prepared in accordance with the questionnaire technique and information was obtained from the source people residing in Gaziantep city center. The yataküstü tradition is a practice among women in the girl's house on a specified day in the week before the dowry is taken to the new couples' home. The dowry prepared here is exhibited to the invited guests. Guests who come to yataküstü gifts to complete and support the dowry. The nature of this gift has changed from past to present in the form of goods, gold and money. For gifting around the transitional periods and other social hadiths in the region, the forefree words are used. The principle of reciprocity is essential in the gift. When the gift is not paid for, the price is requested in a way according to the nature of the gift given before. The degree of kinship and reciprocity determines the value of the gift brought to the yataküstü. Close relatives are obliged to complete the shortcomings of the dowry. The yataküstü tradition is a gathering that includes displaying the skills and handcrafts of the dowry, entertainment among women, music, oral culture and literature, and food and beverage activities. Accordingly, in the article, it was concluded that the yataküstü tradition in Gaziantep marriage ceremonies has multifaceted socio-economic and cultural functions. Marriage is an area of social solidarity and sharing that requires the collective participation of the society. In this context, the yataküstü ceremony, which is included in Gaziantep marriage traditions, is discussed as a model of solidarity and sharing in this article. The yataküstü ceremony is also locally known as dowry. In Gaziantep folk culture, the dowry is taken from the house of the bride and taken to the house where the bride and groom will live one week before the wedding, with a ceremony accompanied by a drum and zurna. On a determined day in the week before the dowry is taken, this day is usually Thursday, and the yataküstü ceremony is held. Yataküstü is a ceremony where the dowry is displayed to the invited guests and the visitors bring gifts to complete the dowry's deficiencies. Only women can attend the yataküstü ceremony in the girls' house. Both boys and girls can be invited to the ceremony. The yataküstü ceremony turns into an indoor entertainment among women and is a day where songs and folk songs are played, accompanied by music, praises and bridesmaids are sung, and special local dishes are prepared for today. Most of the expenses of the yataküstü ceremony are covered by the male side. Thus, economic solidarity is provided between families. In the article, it is examined that the practice of "foremost gift" constitutes a space for socio-economic sharing and cultural transfer within the yataküstü ceremony, which is a marriage tradition. People invited to the yataküstü ceremony in Gaziantep definitely participate in this ceremony by receiving gifts. The principle of reciprocity is essential in this gift. The gifts received are recorded in the dowry book and then taken away. The fact that the gift given is more valuable than the gift is a sign of dignity. It is condemned by the society that the gift given is not repaid. The nature of the gift taken to the yataküstü varies according to the degree of kinship. Close relatives are able to bring more valuable gifts according to their needs in order to make up for the shortcomings of the dowry. From negative cultures until today, ceremonies also shape cultural life as a field of social communication and consumption. Social ceremonies are one of the ways society is remembered and the future is built. In these areas, the community maintains its existence by social solidarity and economic sharing. In this context, it was concluded in the article that the yataküstü ceremony, which is a part of Gaziantep marriage traditions, has the functions of solidarity, solidarity and cultural transfer along with the practice of the öndüç gift. 